higher surface tension, which in turn causes a shear-driven movement of the contained fluid. Besides allowing membrane material and small particles to be transported between individual containers, charged materials can also be transported by electrophoresis in addressed nanotubes by application of an electric potential over two nanotube-connected liposomes (results not shown).

In addition to applications relating to chemical and physical processes in cell systems as well as chemical computation, large and complex fluid membrane networks can be used as templates for designing solidstate devices with potential applications in microfluidics and microelectronics ${ }^{6,10}$.

Anders Karlsson, Roger Karlsson,

Mattias Karlsson, Ann-Sofie Cans,

Anette Strömberg, Frida Ryttsén,

Owe Orwar ${ }^{\star}$

Department of Chemistry, Gothenburg University,

SE-412 96 Göteborg, Sweden

e-mail:orwar@amc.chalmers.se

*Present address: Department of Physical

Chemistry, and Microtechnology Centre, Chalmers University of Technology, SE-41296 Göteborg,

Sweden

1. Bucher, P., Fischer, A., Luisi, P. L., Oberholzer, T. \& Walde, P. Langmuir 14, 2712-2721 (1998).

2. Chiu, D. T. et al. Science 283, 1892-1895 (1999)

3. Karlsson, M. et al. Anal. Chem. 72, 5857-5862 (2000).

4. Sciaky, N. et al. J. Cell. Biol. 139, 1137-1155 (1997).

5. Laplante, J.-P., Pemberton, M., Hjelmfelt, A. \& Ross, J. J. Phys. Chem. 99, 10063-10065 (1995).

6. Evans, E., Bowman, H., Leung, A., Needham, D. \& Tirell, D. Science 273, 933-935 (1996).

7. Moscho, A. et al. Proc. Natl Acad. Sci. USA 93, 11443-11447 (1996).

8. Fredriksson, C. et al. J. Mater. Sci. Mater. Med. 9, 785-788 (1998)

9. Waugh, R. E. \& Hochmuth, R. M. Biophys. J. 52, 391-400 (1987)

10. Schnur, J. M. Science 262, 1669-1676 (1993).

\section{Marine ecology}

\section{Worms start the reef-building process}

or reefs to form in wave-swept environments, the sessile organisms that build them need stable foundations ${ }^{1,2}$. Here we provide evidence that marine worms actively create patches of stable habitat on the sea bed which provide them with food and shelter. In so doing, they bring reef-building organisms together on hard surfaces and so create suitable conditions for reefs to develop.

While maintaining a tropical marine aquarium, we noticed that three small colonies (each weighing 5-20 g) of the scleractinian reef coral Lobophyllia hemprichii on the tank's sandy bed had moved $6-16 \mathrm{~cm}$ during the night. The corals had become attached by a glue-like substance to a fist-sized lump of reef rock covered in
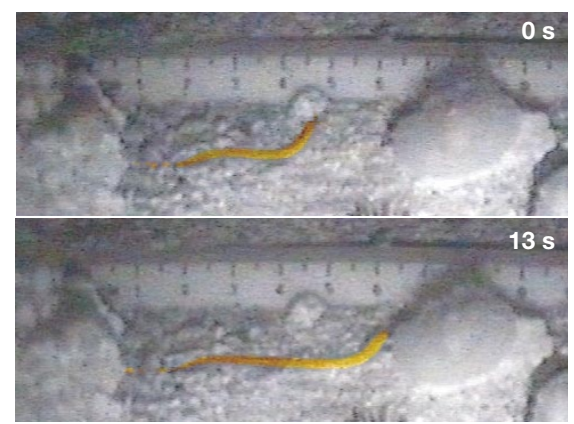

$13 s$

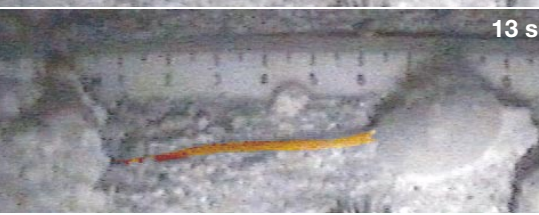

$14 \mathrm{~s}$

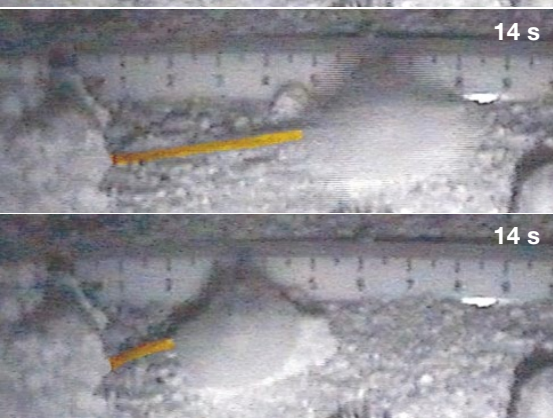

Figure 1 Patch reef construction by a eunicid worm in a ree aquarium. Time-series images, captured from a video recording made under infrared illumination, of the rapid repositioning of a live scleractinian coral from sand bed to solid rock by a eunicid worm for the purposes of habitat assembly. The worm has been coloured to enhance visibility and the images have been adjusted using Adobe Photoshop to improve luminosity and contrast. The ruler in the background is graduated in centimetres and millimetres.

coralline algae. Two colonies were stuck to the side of the rock about $2-4 \mathrm{~cm}$ above the sand bed.

We detached the corals from the reef rock and returned them to their former locations. The corals made night-time journeys to the reef rock 21 times over a 1 -month period. A 90-degree alteration in the position of the reef rock with respect to the corals, or of the corals with respect to the reef rock, resulted in similar agglomeration around and affixation to the upper or lower sides of the rock.

We made several unsuccessful attempts to film this process under very weak background incandescent white or red light (less than $3 \mu \mathrm{mol}$ photons $\mathrm{m}^{-2} \mathrm{~s}^{-1}$ ) and intermittent weak white or red light (1 minute on, 15 minutes off). Under constant background lighting, there was no movement of corals to the rock. During intermittent light-dark cycles, the corals moved on some occasions, but always during the dark period. This indicated that the corals were being moved rapidly by some photophobic agent.

We next mounted a Hi-8 video camera, equipped with infrared emission, perpendicular to the aquarium overnight. Less than 1 hour after darkness, the head and upper body of a bootlace-thick eunicid worm appeared from a hole in the rock. The worm sought out a coral and dragged it to the reef rock in less than 2 seconds (Fig. 1).

The persistent nightly efforts of the eunicid worm shown in Fig. 1 to expand and elaborate a durable habitat for itself suggest that such behaviour must have a genetic basis. Although immature, the worm shown in Fig. 1 could raise a $10 \mathrm{-g}$ piece of coral above the sand bed of the aquarium and cement it, with its photosynthetic tissue orientated upwards, to the side of a piece of reef rock. Fully grown eunicid worms, which can be more than 2 $\mathrm{m}$ long ${ }^{3}$, must be able to assemble and bind together sizeable mounds of hard substrata.

The fossil record shows that the initial growth of coral reefs depends on the aggregation of sessile, skeleton-forming biota on a hard base $\mathrm{e}^{1,2}$. It is not clear how these conditions arise on the shifting seafloors of continental shelf margins. Habitat construction by eunicid and related worms for protection and sustenance is a plausible explanation for both the patchy distribution of benthic communities in general and the development of coral reefs on otherwise unstable substrata ${ }^{1}$. By dragging together reef-building organisms and cementing them to mounds of hard substrata, they can assemble spatially heterogeneous, threedimensional structures that trap sediments ${ }^{1}$, enhance settlement and growth of resident species $^{4}$ and other reef biota ${ }^{1}$, and provide refuges for cryptic communities ${ }^{5,6}$.

J. R. M. Chisholm ${ }^{\star}$ R. Kelley $\dagger$

*Observatoire Océanologique Européen, Centre

Scientifique de Monaco, Avenue Saint-Martin, MC 98000, Monaco

e-mail: j.chisholm@libertysurf.fr

†Watermark Films, PO Box 1859, Townsville,

Queensland 4810, Australia

1. Wood, R. Reef Evolution (Oxford Univ. Press, 1999).

2. Jackson, J. B. C. Am. Nat. 111, 743-747 (1977).

3. Parker, S. P. Synopsis and Classification of Living Organisms 2 18-19 (McGraw-Hill, New York, 1982).

4. Jackson, J. B. C. Bull. Mar. Sci. 39, 588-606 (1986).

5. Jackson, J. B. C. \& Winston, J. E. J. Exp. Mar. Biol. Ecol. 57, 135-147 (1982)

6. Adey, W. H. \& Steneck, R. S. in The Ecology of Deep and Shallow Coral Reefs Vol. 2 (ed. Reaka, M. L.) 163-187 (Office of Undersea Research, NOAA, Rockville, 1985).

\section{erratum}

Docking of components in a bacterial complex

reply from M. Bochtler, C. Hartmann, H. K. Song,

R. Ramachandran, R. Huber

Nature 408, 668 (2000)

The meaning of the last sentence was inadvertently altered during editing by introduction of the word "also", which wrongly gave the impression that our mutational results unambiguously support the EM docking mode. The intention in our reply was to indicate that neither of the two observed docking modes can entirely explain the available mutational and functional data. 